\title{
First Time Experience of Being a Father in Adapting to Postpartum Period in Indonesia Setting
}

\author{
Winarsih Nur Ambarwati ${ }^{*}$, Risalatul Ikhtiarini ${ }^{2}$ \\ ${ }^{1}$ Maternity Nursing Department, School of Nursing, Universitas Muhammadiyah Surakarta, Kartasura, \\ 57162, Central Java, Indonesia. \\ ${ }^{2}$ School of Nursing, Universitas Muhammadiyah Surakarta, Kartasura, 57162, Jawa Tengah, Indonesia. \\ *corresponding author :wna246@ums.ac.id
}

\begin{abstract}
Abstrak: Periode post partum adalah transisi luar biasa bagi seorang ayah dalam pengalaman pertamanya. Hasil penelitian menunjukkan bahwa ayah memiliki peran yang sangat besar dalam kesehatan dan kesejahteraan ibu dan anak. Namun, seringkali ayah mengalami kesulitan dalam beradaptasi dan menjalankan perannya karena kurangnya pengetahuan, keterampilan dan dukungan. Tujuannya adalah untuk mengeksplorasi pengalaman ayah dalam beradaptasi dengan periode postpartum. Penelitian ini adalah penelitian kualitatif dengan studi fenomenologi deskriptif. Teknik pengambilan sampel dilakukan secara purposive sampling. Jumlah peserta adalah 10 ayah yang mendapatkan anak pertama mereka. Data dikumpulkan melalui wawancara mendalam. Data dianalisis dengan metode Colaizzi. Hasilnya adalah pengalaman psikologis pertama menjadi seorang ayah dalam beradaptasi dengan postpartum termasuk perasaan positif dan negatif. Kesimpulan dari penelitian ini adalah pengalaman pertama Ayah dalam beradaptasi dengan postpartum yaitu memiliki perasaan negatif yang lebih dirasakan. Tenaga kesehatan dituntut untuk dapat memahami kondisi psikologis ayah dan dapat memberikan dukungan yang diperlukan sehingga ayah dapat beradaptasi dengan baik dan memiliki pengaruh positif pada ibu dan bayinya.
\end{abstract}

Kata kunci: Pengalaman Pertama Kali, Ayah, Periode Pascapersalinan, Adaptasi

Abstract: The post partum period is an extraordinary transition for a father in his first experience. Research results have shown that fathers have a very large role in the health and welfare of mothers and children. However, often the father has difficulty in adapting and carrying out his role due to lack of knowledge, skills and support. The objective of is to explore fathers' experience in adapting to postpartum period. The research design is qualitative research by descriptive phenomenology study.Technique sampling is by purposive sampling. The number of participants is 10 fathers who get their first child. Data were collected through indepth interviews. Data were analysed by Colaizzi method. The result is the first psychological experience of being a father in adapting to postpartum includes positive and negative feelings. Positive feelings include happiness and gratitude. Negative feelings include confusion, difficulty adapting to new roles, feeling worried, changing patterns of relationships with wives, feelings of neglect, expected and required to be able to understand wives and provide support, lack of information from health workers relating to postpartum care. The conclusion, Father's first experience of adapting to postpartum is more perceived negative feelings. Health professionals are required to be able to understand the psychological condition of the father and able to provide support so that the father can adapt well and have a positive influence on the mother and baby.

Keywords: First Time Experience, Father, Postpartum Period, Adapting 


\section{INTRODUCTION}

The postpartum period is an extraordinary transition time, which can be a challenge for couples who have their first child. Although happiness is abundant because of the presence of a new family member. This can be a difficult and confusing time for couples which can lead to a crisis situation. In the postpartum phase, mothers and fathers have a similar amount to change to adapt with new role and situation (Doss, 2009). The mothers underwent massive physical and psychological transformation. For first-time fathers, research shows that in the postpartum period fathers also face significant challenges and time changes (St John et al., 2005)

Interestingly, like postpartum mothers, in fact, a first-time father experiences various psychological changes in adapting to the postpartum period. Fathers found this circumstance to be a stressful time which was marked by fatigue, poor concentration and irritability (Darwin et al., 2017). According to Lindberg \& Engström (2013), a first-time father will feel abandoned and ignored because the couple's attention is focused on the new object. An everyday stressor for a first-time father is more likely to be related to role functions (Pollock, 2005).

There has been a growing body of knowledge research on fatherhood for the last decades. However, knowledge about fatherhood at a specific time, namely the postpartum period is still very little known. In response, this research was conducted to provide the purpose of understanding the unique circumstances experienced by first-time fathers during the postpartum period in Central Java, Indonesia. This research is contributed to enrich the state of the art of knowledge about fatherhood, especially with Asian backgrounds.

\section{METHODS}

This type of research is a qualitative descriptive study with a phenomenological study approach. The sampling technique uses purposive sampling. Criteria for inclusion of fathers who have a first child have a wife within two weeks postpartum. The baby is born alive and healthy. The number of participants is ten people. This research instrument uses interview guidelines, stationery such as books and ballpoints, voice recorder (recorder handphone Oppo A71). Data were collected through in-depth interviews. The credibility test/trust test of the results of this study includes the member check test for participants. Data were analyzed by qualitative analysis with Colaizzi method.

\section{RESULTS}

\section{Participants Characteristics}

The number of participants is 10 people. Age of participants between 23-35 years, all participants are Muslim, Javanese and Indonesian citizens. Five fathers graduated from secondary and tertiary school, five fathers from higher education.

\section{Positive and negative feelings}

There are two main themes, namely positive feelings and negative feelings. For subtheme of positive feelings includes feeling happy and proud to be fathers. Furthermore, sub-themes for negative feelings, namely confusion, difficulty adapting to new roles, worry, changing patterns of relationship with wife, feeling expected and required to be able to understand the wife and provide support, feel the lack of information from health workers related to care.. 


\section{DISCUSSION}

\section{Feeling happy and grateful}

"... feeling very happy because it has been coveted before ..." (p1). "Happy because now the house is more crowded" (p2). "Very happy and mixed with gratitude ..." (p3). "My feelings are mixed as happy, thankful, thank you, for God" (p4). now has a son ... "(p5)." It must be very happy, miss, because it was bestowed by God ... "(p6). happy because indeed this moment I have been dreaming of for a long time ... "(p8)." ... certainly happy, always grateful ... "(p9)." ... feeling happy because of having children "(p10). Psychological feelings of fathers who have their first child are various, one of which is feeling happy and grateful. The feeling of pleasure is due to various reasons, including because they have craved to have children, the condition of the house becomes more crowded because of the addition of new members in the family, grateful for God's grace. The father feels admiration for the behavior of the baby causing a feeling of increased love and responsibility for the family that changes his view of life (Deave \& Johson, 2008). Father feel mixed feelings between feeling happy, surprise and confused (Chin \& Daiches, 2011).

\section{Proud to be father}

"... his vocation status also changed to a father ..." (P2). "... glad I am now a father, hopefully can be a good father ..." (P4). "... proud of being called a father and having to work harder" (P5). "... now has become a father, and this is a feeling of pride too" (P10).

Father feels proud of his new role as a father and hoping to be a good father. Having children and being parents for Javanese and Muslims is a very desirable and proud thing because it is a successor to the family lineage, and is a guarantee in old age (Yana, 2012). In addition, in Javanese culture, a man who has children is considered to have succeeded in carrying out his duties as a husband in the family (Yana, 2012). An exciting and full of happiness felt by a father when he became a father (Deave \& Johson, 2008). Fathers have the desire and motivation to be a good father part of developing their identity during their transition to fatherhood.

\section{Confuse}

"I'm still confused what if the baby cries and what to do,... "(R1 \& R5). "... when babies are fussy and I have to do it, I still learn to understand the meaning of crying" (R2). "... confused, the crying must understand what the baby's crying means" (R4). "Difficulties persist, for example the little fuss or cry is due to what and what should I do" (R9).

Feelings of confusion felt by a father are caused by ignorance of the father in interpreting the crying baby and what to do. The situation made the fathers confused about what to do. Father experiences various emotional reactions to his new role as a father, besides feeling more responsible towards his family and great love, a father also feels overwhelmed and confused about his new role (Chin \& Daiches, 2011).

\section{Difficulty adapting to new roles}

"Difficulty dividing time between family, work and caring for my mother because it affects my routine. .... " (R1). "Difficulty dividing work time, at home. ... now I have to help a lot and be more independent 
.... " (R2). "... In dividing time with family "(R7). "... because the responsibilities of fathers become automatically increased the division of time must be even more maximal ... (R10).

Adapting in the postpartum period, makes fathers experience psychological feelings of difficulty in their roles, such as difficulty dividing time between family, work and caring for other family members such as mothers, difficulty adjusting early to the child and difficulty playing new roles as fathers. Depression in the postpartum can occur when the father is not ready for the speed of change that occurs in the family, difficulty in playing the role as a father because in a new role added will affect the routine every day, lack of emotional support from a partner, and fear of failing to carry out his role (Mahmoodi et al. , 2017). The source of a stressor for a new father is more related to the function of his role as husband, father, responsibility towards other family members (Pollock et al., 2005). The situation is felt to be difficult when fathers are demanded to have to adapt quickly while supporting resources are not or little available.

\section{Changing patterns of relationship with wife}

"Little has changed because my wife prioritizes the baby more than when we were together" (p1). "There is a change in relationship, there is a distance limit as in marital relations, ..." (p2). "If the closeness is clearly reduced more because of the time together with my wife so rarely" (p4). "... because my wife has more time with my child (p5, p9). " now after giving birth the wife wants to be closer to her mother (p10).

The feeling that there is a change in the pattern of relationship to the wife is also felt by the novice father in the postpartum period. This change in relationship pattern is due to the wife prioritizing and dedicating time to the baby causing reduced attention and opportunity together with her husband, this creates a feeling of being ignored, separated, and there is a distance between husband and wife.

Fathers experience some unexpected changes in relationships with their partners, such as not being able to spend time together as a partner and lack of intimate relationships with partners, but in this case a father also works together to help each other in carrying out his new role as new parents (Chin, Hall \& Daiches, 2011; Genesoni \& Tallandini, 2009). The wife is also closer to her mother because the wife's mother or parents-in-law in the Javanese family have an important role in providing support for the daughter or daughter-in-law as a source of emotional, functional support for baby care, and even financially The Indonesian community has a very strong kinship relationship. This kinship provides sources of support for the family because the family can be a source of physical, mental, and financial support (Riany, 2016). According to Lindberg \& Engström (2013) a father feels abandoned or ignored because the mother's attention is more focused on new objects. Deave, Johnson, \& Ingram (2008) also found that fathers often felt unprepared for changes in partner relationships such as feeling tense when carrying out their new roles as parents and lacking partner time to communicate with each other.

\section{Feeling expected and required to be able to understand the wife and provide support}

"... when my wife has a mood disorder I can understand, ..." (p1). "I have to be more mature and patient because that's the risk after giving birth, there is a psychological change from the mother like moody" (p5). "Give an understanding of the situation and conditions being experienced such as mood swings" (p7). "... I just understand being able to put my position in these conditions. I leave her first and then when she calms down I approach her. (p8). 
Mothers after giving birth can experience mood changes suddenly and change such as irritability and sensitivity. This condition makes fathers expected and demanded to be able to understand and provide support to their wives in overcoming wife's disturbance. Being mature, more patient, understanding and when the wife is not in the mood the husband chooses not to respond by being calm. According to Darwin et al., (2017) the birth of a first child is a new experience for a father, where the father has several changes in his life. A father puts great emphasis on the couple in meeting their needs, protecting and maintaining partnerships. The role of fathers, in this case, is to provide open support to couples from feelings of stress and focus in carrying out the role of a mother.

\section{Feel the lack of information from health workers related to care.}

"... the education provided is related to the postpartum period ..." (p1). "I have never played the role of father. "(p4). "The lack because not given an example first. (p5). "... I feel a little lack of support from health workers related to the new role of the father in the period after the wife gave birth like what ..." (p6). "Only told to pay attention to the wife's intake. (p8). "If there is no information related to the role of husband, the information given is more to mothers and children." (p9).

Father felt the lack of information from health professionals related to the husband's role. Lack of information makes it difficult for dad to adapt to his new role. Health workers are more focused in providing information related to the care of their wife and baby so that in this case the father feels less attention is paid to his adaptation to carry out his new role as a father.

Prospective fathers and new fathers want specific information about how to carry out their new role as a father and how to care for babies (Deave \& Johnson, 2008). Besides that, according to Deave \& Johnson (2008), Premberg \& Lundgren (2006), Tighe, Health, \& Lecturer (2010) said that the need for health professionals to hold special discussions with new fathers and new fathers to make them feel more involved and able to control the situation during the postpartum period. New parents also want information during the postpartum or postnatal period of health workers to provide guidance when new parents feel uncertain (Danbjorg, Wagner, \& Clemensen, 2014). So in this case, it is necessary to have a program of health professionals where the program is able to help fathers adapt and carry out their new roles during the postpartum period.

\section{CONCLUSION}

This research identifies the positive and negative psychological experiences of being a father who has the first child to adapt during the postpartum period. Positive psychological experiences such as feeling happy and proud to be a father. Negative psychological experiences include confusion and worry, difficulty adapting to new roles, changing patterns of relationships with wives, feeling neglected, expected and required to be able to understand wives and provide support and lack of information from health workers related to the husband's role. The negative psychological experience of the father is more than the positive one.

This finding implies the importance for health professionals to support their husbands in their role during the postpartum period. This can be done with education, counselling, involving fathers in maternal health care since pregnancy, and the existence of support groups such as peer support that can be facilitated by health care providers or integrated into primary health services. 


\section{REFERENCES}

Chin, R., Daiches, A., \& Hall, P. (2011). A qualitative exploration of first-time fathers' experiences of becoming a father. Community Practitioner, 84(7), 19-23.

Danbjorg, D.B., Wagner, L., Clemensen, J. (2014). Do families after early postnatal discharge need new ways to communicate with the hospital? A feasibilility study. Midwifery, 30, 725- 732.

Darwin, Z., Galdas, P., Hinchliff, S., Littlewood, E., McMillan, D., McGowan, L., \& Gilbody, S. (2017). Fathers' views and experiences of their own mental health during pregnancy and the first postnatal year: A qualitative interview study of men participating in the UK Born and Bred in Yorkshire (BaBY) cohort. BMC Pregnancy and Childbirth, 17(1), 1-15. https://doi.org/10.1186/s12884-017-1229-4.

Deave, T., Johnson, D. (2008). The transition to parenthood: what does it mean for fathers?, Journal of Advanced Nursing 63, 626-633.

Deave, T., Johnson, D., \& Ingram, J. (2008). BMC Pregnancy and Childbirth early parenthood, 11, 1-11. https://doi.org/10.1186/1471-2393-8-30.

Doss, B. D.Rhoades, G. K.Stanley, S. M.Markman, H. J.(2009). The effect of the transition to parenthood on relationship quality: an 8-year prospective study, J Pers Soc Psychol, Vol. 96, 3, p.601-619.

Edleson, J.L. (2016). Becoming a good father: The developmental engine of first-time fatherhood. Fathering, Vol. 13 ISSUE 3 Winter 2015/16.

Engqvist, I., \& Nilsson, K. (2011). Men's experience of their partners' postpartum psychiatric disorders: narratives from the internet. Mental Health in Family Medicine, 8(3), 137-146. Retrieved from http://www.ncbi.nlm.nih.gov/pubmed/22942895.

Finnbogadóttir, H., Crang Svalenius, E., \& K Persson, E. (2003). Expectant first-time fathers' experiences of pregnancy. Midwifery, 19(2), 96-105.

Lindberg, I., \& Engström, Å. (2013). A qualitative study of new fathers' experiences of care in relation to complicated childbirth. Sexual and Reproductive Healthcare, 4(4), 147-152.

Mahmoodi, H., Golboni, F., Nadrian, H., Zareipour, M., Shirzadi, S., \& Gheshlagh, R. G. (2017). Motherfather differences in postnatal psychological distress and its determinants in Iran. Macedonian Journal of MedicalSciences, 5(1), 91-96.

Nelson, A.M., (2003). Transition to motherhood. JOGNN 32, 465-477.

Pollock, M. A., Amankwaa, L. C., \& Amankwaa, A. A. (2005). First-time fathers and stressors in the postpartum period. The 1 of Perinatal Education, 14(2), 19-25.

Riany, Y.E., Meredith, P., \& Cuskelly, M. (2017) Understanding the Influence of Traditional Cultural Values on Indonesian Parenting, Marriage \& Family Review, 53:3, 207-226.

St John, W.Cameron, C.McVeigh, C. (2005). Meeting the challenge of new fatherhood during the early weeks, J Obstet Gynecol Neonatal Nurs, 34, 2, p. 180-189

Tighe, S. M., Health, W., \& Lecturer, P. H. N. (2010). An exploration of the attitudes of attenders and non-attenders towards antenatal education. Midwifery, 26(3), 294-303. https://doi.org/10.1016/j.midw.2008.06.005

Yana. 2012. Falsafah dan pandangan hidup orang Jawa, Bintang cemerlang, Yogyakarta. 